\title{
Psychological Meaningfulness and Work Engagement Effect on Doctor's Job Satisfaction
}

\author{
Sylvia Diana Purba ${ }^{\star}$, Chaterine, Saebani Hardjono, Bella Clarissa
}

Faculty of Economics and Business, Universitas Katolik Indonesia Atma Jaya, Jakarta, Indonesia

\section{Info Article}

History Article:

Submitted 26 August 2019

Revised 18 December 2019

Accepted 26 December 2019

\section{Keywords:}

Job Satisfaction; Psychological

Meaningfulness; Work Engagement.

\begin{abstract}
This research aims to investigate the job satisfaction of the doctors with psychological meaningfulness and work engagement as antecedent variables, in Java, Indonesia. The sampling technique used in this research was convenience sampling method and snowball sampling method. To analyze the data, this research used the SEM program, assisted with AMOS 23. The results of this study indicate that psychological meaningfulness effect on work engagement. However, no effect on job satisfaction. While the work engagement has an effect on job satisfaction. The work engagement is significant as intervening variable in the influence of psychological meaningfulness toward job satisfaction. These results support the work situation of doctors in Indonesia who have high workloads but can still feel job satisfaction. High work engagement will make the doctors feel enthusiasm and dedication even though the workload is high with abnormal work hours. These results support the work situation of doctors in Indonesia who have high workloads but can still feel job satisfaction.
\end{abstract}

\section{Kepuasan Kerja para Dokter dengan Efek Kebermaknaan Psikologis dan Keterikatan Kerja}

\begin{abstract}
Abstrak
Penelitian ini bertujuan untuk menyelidiki kepuasan kerja para dokter dengan kebermaknaan psikologis dan keterikatan kerja sebagai variabel anteseden, di Jawa, Indonesia. Teknik pengambilan sampel yang digunakan dalam penelitian ini adalah metode convenience sampling dan metode snowball sampling. Untuk menganalisis data, penelitian ini menggunakan program SEM, dengan AMOS 23. Hasil penelitian imenunjukkan bahwa kebermaknaan psikologis berpengaruh pada keterikatan kerja. Namun, tidak berpengaruh pada kepuasan kerja. Sedangkan keterikatan kerja berpengaruh terhadap kepuasan kerja. Keterikatan kerja berpengaruh signifikan sebagai variabel mediasi dalam pengaruh kebermaknaan psikologis terhadap kepuasan kerja. Tingginya keterikatan kerja akan membuat para dokter merasa lebih antusias dan berdedikasi meskipun tekanan pekerjaan tinggi dengan jam kerja diluar dari normal. Hasil ini mendukung bahwa situasi kerja para dokter di Indonesia, meskipun dengan beban kerja yang tinggi mereka masih dapat merasakan kepuasan kerja.
\end{abstract}

JEL Classification: M3, M31

How to Cite: Purba, S. D., Chaterine., Hardjono, S., \& Clarissa, B. (2019). Psychological Meaningfulness and Work Engagement Effect on Doctor's Job Satisfaction. Jurnal Dinamika Manajemen, 10(2), 229-239.

${ }^{\bowtie}$ Correspondence Address

Jl. Jend. Sudirman No.51, Jakarta Selatan, Daerah Khusus Ibukota Jakarta, 12930

Email: rsylviadianapurba@gmail.com 2086-0668 (print) 2337-5434 (online) DOI: $10.15294 /$ jdm.v10i2.20835 


\section{INTRODUCTION}

Baharuddin et al. (2017) writes the "Regulatory Ethics Review of Doctor Working Hours in Indonesia" it causes of the excessive workload of physicians that result in longer doctor work hours. A Comparison of doctors with the Indonesian population is still quite unideal, making the ratio between patients and doctors unbalanced. In addition, the impact of the excessive workload will hurt the health of the physician and affect the patient's safety.

The organization needs to maintain the health workforce, especially doctors with regard to physician's job satisfaction through regulatory policy and facility provision. One of the policies that can be made for doctors is the doctors' working hours, because the issues raised about the number of hours of doctor work is excessive.

In Indonesia cases, there is no specific regulation of doctor's working hours. But in reality, the rules of labor hours have been written in the Indonesian Law in Article 77 paragraph (2) of Law no. 13 of 2003 on employment, that a worker's work hours are seven hours a day (for six working days of the week) or eight hours a day (for five working days per week). However, doctors usually practice in three places at once owned by the government, private or private practice in accordance with the Minister of Health RI regulation number 512/MENKES/ PER.IV.2007 about Practice License and Implementation of Medical Practice. A doctor often works longer than the rule. If doctors work too long work and then the performance of doctors will be reduced, and will give a side effects, such as the level of error in taking of medical action, as a higher misdiagnosis of patients to the risk of accidents on the way back home after work.

The problem of physician working hours that work more than eight hours so that the ability to analyze the disease or prescription drugs can be reduced. Discussing the hours of specialist doctors cannot be equated with civil servants' working hours. This article discusses the hours doctors work cannot be the same as civil servants who can go home and come on time according to the applicable hours. A doctor cannot refuse a patient, especially a patient who needs surgery. By looking at the issues regarding the doctor's working hours above, this study will discuss whether doctors can still feel satisfaction in their work?

There are several ways that can be done to improve job satisfaction for employees, such as make jobs fun, pay people fairly, match people to jobs that fit their interests, and last avoid boring, repetitive jobs (Greenburg \& Baron, 2003). A doctor needs to enjoy their work, because his work is quite challenging and need seriousness in working. In addition there are some points that "match people to jobs that fit their interests" which means matching people with work that suits to them. When a person working as a physician is expected to fit their intentions, realize the profession of a doctor is a profession that deals with the health and condition of one's individual.

Psychological meaningfulness of work is a psychological understanding for someone who is living in his profession (Oliver \& Rothman, 2007). The doctors realize that their work is very useful for many people if done right. Saving individual lives from illness is not easy and has a great responsibility for doctors. When a person finds the meaning of a job beneficial to many and brings a positive impact around it, he will feel more emotionally attached to his work, making his work something fun (Albrecht et al., 2015)

When a worker feels engaged to his work, it will improve organizational performance in a positive way (Karatepe \& Demir, 2013; Daley, 2017), which is one of the key indicators of the company's success as it affects job satisfaction, turnover intention, and customer satisfaction (Yin, 2018). From the description, work engagement very interesting to the inquisitive, that is knowing how much emotional bond the doctors to where he worked and his own work.

The job satisfaction of a doctor from several previous studies is known to be influenced by various factors. One study in China stated work family conflicts and good relations between patients and doctors had a significant influence on job satisfaction (Deng et al., 2018). Another study in China (Yu et al., 2018) stated that doctor job 
Sylvia Diana Purba et al./ Psychological Meaningfulness and Work Engagement Effect on Doctor’s Job....

satisfaction is very related especially to work itself besides the work environment. This is also relevant to the results of the survey in Nigeria (Martins et al., 2016), the doctor's job satisfaction is high for work itself and low for remuneration. This means that doctors still feel job satisfaction with their work despite being underpaid. While in Indonesia research shows that the organizational commitment of doctors is relatively low and they usually work in more than one organization, in carrying out his profession (Setyowati et al., 2017).

This research has a novelty from the doctor's perception of their job satisfaction. It is about how they love their work and this makes them engaged. It is assumed they have a work engagement that makes them satisfied at work. As stated earlier that loving a job has a psychological meaning that presents job satisfaction. Therefore in Indonesia doctors often work in several hospitals and clinics. This is certainly not recommended even though there are quite a lot of patients served. They seek income from several workplaces. However, do they feel job satisfaction with their work?

\section{Hypothesis Development \\ Relationship between Psychological Mea- ningfulness and Work Engagement.}

As part of the meaning in life, the concept of meaningfulness is divided into two aspects, namely (1) meaningful work, and (2) psychological meaningfulness. Meaningful work (Steger et al., 2012) as a working relationship with people. Meaningful work as the degree to which employees experience the work as something that is generally valuable, meaningful, and rewarding (Geldenhuys et al., 2014). Psychological meaningfulness as a value of the goal or purpose of the work as well as a value of the individual's own standards (May et al., 2004). The lack of meaning in work can reduce the sense of work engagement.

Psychological meaningfulness at work is to make contribution optimally to the organization (Steger \& Duffy, 2012; Ugwu \& Onyishi, 2018; Cai et al., 2018). Work experience to achieve the purpose of life becomes the basis for explaining the meaning of work to everyone. Psychological meaningfulness is the unity between personal goals, the value of life, social relationships and the various activities that are subjected to one's life (Albrecht et al., 2015). Therefore, it is necessary to balance the dimensions of the self (mental, physical, emotional, and spiritual) to meet the achievement of psychological meaningfulness.

Psychological meaningfulness is related to the achievement of goals, the fulfillment of the value of life, the achievement of self efficacy, and self-esteem (Abbas et al., 2014). It involves many areas of life, including work. A person who feels meaningful if they can be useful and valuable to his organization.

There are three dimensions (Steger et al., 2012) of psychological meaningfulness, (1) positive meaning, which reflects the subjective experience to captures how one views of the meaning and meaning of its work; (2) meaning, which is related to how one looks at its work, but how one tries to shape its work according to its purpose and value of life; (3) high motivation, which explains how individual has a spirit to do something.

Engagement means being involved, committed, passion, enthusiasm, focus on effort and energy (Imperatori, 2017). There are studies that reveal, work engagement is an association of higher levels of performance and productivity (Banihani et al., 2013; Asiwe et al., 2014). Work engagement is the synergy of a positive, but indicates that it is also a different concept of being tied to a work characterized by enthusiasm and dissolution in work (Schaufeli et al., 2002). when employees feel tied to their jobs, they will be encouraged to try more optimally. Work engagement reflects to the energy which employees brought in their work (Byrne et al., 2017).

There are three dimensions (Lockwood, 2007) of work engagement, (1) vigor; (2) dedication and; (3) absorption. Passion means devoting energy and mental during work and facing difficult problems keep the spirit. Dedication is associated with enthusiasm, inspiration given to work, and the latter absorption means concentrating fully in doing the work. Meaning- 
ful work have benefits for organizations and lead to positive work outcomes such as satisfied, engaged and committed employees, individual and organizational fulfilment, productivity, retention and loyalty (Kahn, 1990; Asiwe et al., 2017). Psychological meaningfulness contributed to work engagement (Imperatori, 2017). Individuals are likely to be motivated to invest themselves more fully into a given work role activity when they feel personally meaningful (Geldenhuys et al., 2014).

H1: Psychological meaningfulness has positive effect on work engagement.

\section{Relationship between Psychological Mea- ningfulness and Job Satisfaction}

A cross-sectional survey was conducted by Sartono and Ardhani (2015) explains the relationships between three job characteristics constructs, namely work engagement, intrinsic motivation and job satisfaction in a workplace. Implications of the study are that human resource interventions are required in order to deal with enhancing work engagement, intrinsic motivation and job satisfaction. Furthermore, the results indicate that intrinsic motivation and work engagement can improve job satisfaction.

Job satisfaction is closely related to the attitudes of employees to their own work, work situation, cooperation between leaders with fellow employees (Fadlallh, 2015). It can be concluded that the attitudes employed by employees on their work are influenced by the factors generated in their work. Job satisfaction is a positive feeling about work, which is resulting from an evaluation of its characteristics (Sawang, 2012). Job satisfaction is a positive emotional state that results from the evaluation of one's work experience towards his work as a result of employee perceptions of his job.

Employees will develop a positive affection to the organization, if the expected outcomes are met (Sartono \& Ardhani, 2015). This involves employees' appraisal of how well their jobs provide things that are viewed as important usually influenced by an employee's unique experiences, needs, values and expectations. It is important to note that, job satisfaction is a multifaceted construct that comprises both intrinsic and extrinsic job elements (De Witte \& Buitendach, 2015). Furthermore, meaningful work leads to employees functioning better and hence to increased levels of engagement and commitment (Steger \& Dik, 2009; Steger et al., 2012).

H2: Psychological meaningfulness has a positive effect on job satisfaction.

\section{Relationship between Psychological Mea- ningfulness and Work Engagement towards Job Satisfaction}

Job satisfaction becomes central and crucial to management (Adio \& Popoola, 2010). Having an effective and efficient acquisition and great resources, after all, is the overall purpose of management. Human resources are the most important and yet the most unpredictable of all the resources. Job satisfaction is concerned with feelings one has towards the job, motivation or the motivator.

There is close relationship between job satisfaction and psychological well-being (Tanujaya, 2014; Lu et al., 2016). In this study, a dimension that is used to measure the psychological well-being is the autonomy, personal growth, positive relation with others, purpose in life and self-acceptance. In dimension of purpose in life, individuals are intended to have specific goals in life and have control over their selves, feel the meaning of life (past and present), and also have an direction to achieve the purpose of life (Zhong et al., 2016; Noblet et al., 2017; Walden et al., 2017; Ko et al., 2017). We extend this as psychological meaningfulness.

In summary, this study focuses on the importance of how meaningful work contributes towards satisfaction. It highlights the importance of employees experiencing meaningfulness, and hence being positively engaged, and promoting satisfaction at work.

H3: Work engagement has a positive effect on job satisfaction.

$\mathrm{H} 4$ : Work engagement as a mediating variable in the influence of psychological meaningfulness toward job satisfaction. 
Sylvia Diana Purba et al./ Psychological Meaningfulness and Work Engagement Effect on Doctor's Job....

This research framework of this study is shown in Figure 1.

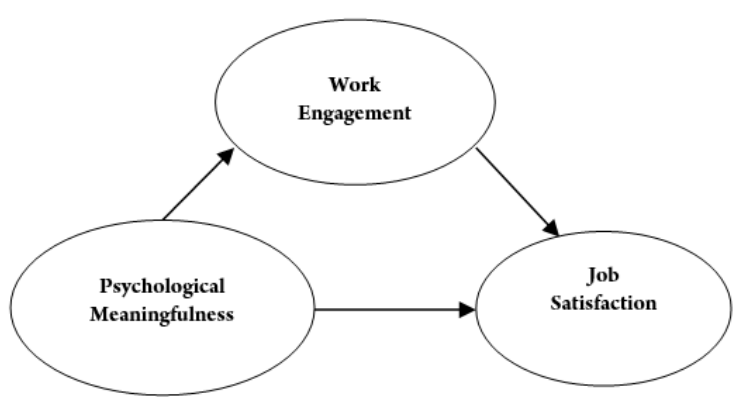

Figure 1. The Research Framework

\section{METHOD}

This research is a quantitative research, by obtaining data through questionnaires. Either distributed online (Gform) or directly. The data obtained as many as 150 doctors, which the following characteristics of respondents (Table 1). The object of this study is the profession of doctors working in hospitals and clinics. Doctor respondents who work in the hospital as much as $72 \%$ and who work in the clinic by $28 \%$. In accordance with the specialization of the physician field, the study is divided into three types of medical fields; general practitioners, specialists and dentists. Most doctors who fill the data of this study are general practitioners with $66 \%$ of the total respondents, $18 \%$ specialists and $16 \%$ of dentists. Based on sex (gender) is divided into two, namely women and men. More women who fill this research data with the number of 90 people or $58 \%$ of the total respondents and men as much as 65 people or $42 \%$ of the total respondents.

Table 1. Characteristics Respondents

\begin{tabular}{ll}
\hline Workplace & \\
\hline Hospital & $72 \%$ \\
Clinic & $28 \%$ \\
\hline Specialization & \\
General practitioners & $66 \%$ \\
Specialists & $18 \%$ \\
Dentists & $16 \%$ \\
\hline Gender & \\
Women & $58 \%$ \\
Men & $42 \%$ \\
\hline
\end{tabular}

Characteristics of respondents by age divided into four age groups. The first group aged 24-34 years with the number of respondents 97 people. The second age group is over $34-44$ years with 25 respondents. The third age group is over 44-54 years with the number of respondents 22 people and last over 54 years as many as 6 people, with the oldest age is 83 years as many as one person. The last respondent's characteristic is based on the length of work of the doctor in his workplace. Divided into three groups, the first with a vulnerable time of $1-5$ years with the number of respondents as many as 85 people. The second group is over 5-10 years with the number of respondents as many as 30 people and the last is a doctor who has worked in the workplace more than 10 years, as many as 35 people. From the acquisition of respondents' answers responses in to the questionnaire, this study processed data using the program of AMOS 20.

Result of mean score and estimation test shows that the overall mean score psychological meaningfulness of 4.81 wich fall into the High category (Table 2). All doctors feel a high workspan. It can be seen that the overall mean score of engagement to employment is 4.67 , which means doctors have a high sense of engagement to work. Finally, it can be seen that the overall mean score of job satisfaction perceived by respondents amounted to 4.44 which means the doctors have a high job satisfaction.

The result from Equation Structural Modeling analysis using AMOS is shown in Figure 2.

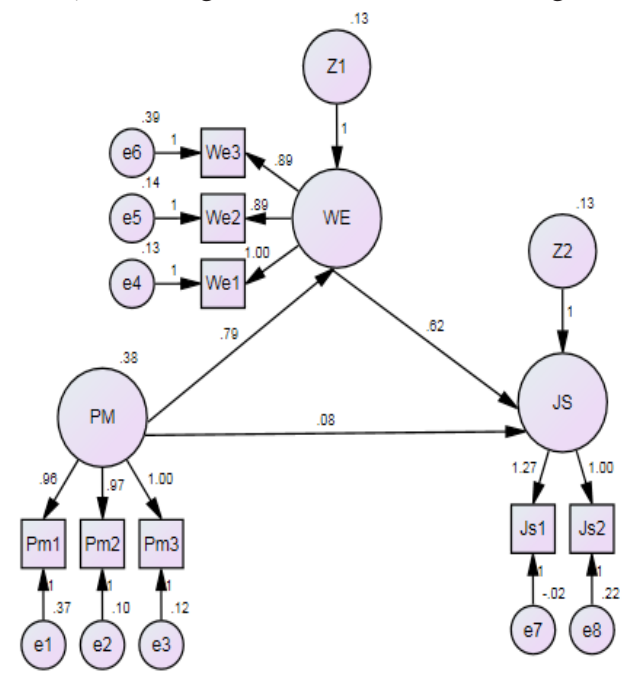

Figure 2. Equation Structural Modeling Analysis 
Jurnal Dinamika Manajemen, 10 (2) 2019, 229-239

Table 2. Mean Score, Estimation, and Reliability Test

\begin{tabular}{llllllr}
\hline Indicators & Mean & & Estimate & Overall Estimate & Reliability Test \\
\hline Meaning Making Through & 4.8 & $\mathrm{Pm} 3 \leftarrow \mathrm{PM}$ & .871 & $\mathrm{WE} \leftarrow \mathrm{PM}$ & .806 & $\mathrm{PM}=0.86$ \\
(MMT) & 4.9 & $\mathrm{Pm} 2 \leftarrow \mathrm{PM}$ & .879 & $\mathrm{JS} \leftarrow \mathrm{PM}$ & .092 & $\mathrm{WE}=0.82$ \\
Positive Meaning (PosM) & 4.8 & $\mathrm{Pm} 1 \leftarrow \mathrm{PM}$ & .696 & $\mathrm{JS} \leftarrow \mathrm{WE}$ & .675 & $\mathrm{JS}=0.91$ \\
Greater Good & 4.8 & & & & & \\
Motivation (GGM) & 4.7 & $\mathrm{We} 1 \leftarrow \mathrm{WE}$ & .857 & & & \\
Overall Means Score PM & 4.9 & $\mathrm{We} 2 \leftarrow \mathrm{WE}$ & .825 & & & \\
Vigor (Vi) & 4.4 & $\mathrm{We} 3 \leftarrow \mathrm{WE}$ & .651 & & & \\
Dedication (De) & 4.7 & & & & & \\
Absorption (Ab) & 4.5 & $\mathrm{Js} 2 \leftarrow \mathrm{JS}$ & .762 & & & \\
Overall Means Score WE & 4.4 & $\mathrm{Js} 1 \leftarrow \mathrm{JS}$ & 1.018 & & & \\
Motivation Factors (Mov) & & & & & \\
Hygiene Factors (He) & 4.4 & & & & & \\
Overall Means Score JS & & & & & & \\
\hline
\end{tabular}

The validity test used is the convergent validity test. Based on the results can be seen all valid data (Table 3), because all sthe loading factor in addition $>0.5$ Based on the estimation test (Table 2), the following data are obtained. It can be seen that there is no influence between psychological meaningfulness with job satisfaction, but psychological meaningfulness has influence to work engagement equal to 0.806 and work engagement to job satisfaction equal to 0.675 .

Table 3. Validity Test

\begin{tabular}{ll}
\hline & Estimate \\
\hline WE $<---$ PM & .806 \\
JS <--- WE & .675 \\
JS <--- PM & .092 \\
Pm3 <--- PM & .871 \\
Pm2 <--- PM & .879 \\
Pm1 <--- PM & .696 \\
We1 <--- WE & .857 \\
We2 <--- WE & .825 \\
We3 <--- WE & .651 \\
Js2 <--- JS & .762 \\
Js1 <--- JS & 1.018 \\
\hline
\end{tabular}

Reliability test used is construct reliability test with value $>0.70$. It can be seen on Table 2 . that all $\mathrm{CR}$ values on each indicator has a value $>0.70$ then it can be said all indicators meet the criteria of this test of reliability, but probability level will decrease. However, in this study using the Maximum Likelihood (ML) technique that is no affected (robust) against multivariate normality deviation (Ghozali, 2009). Thus, the data that used in this study is the primary data obtained directly from the various respondents, making it difficult to obtain data that follows the normal distribution perfectly.

\section{Goodness of Fit}

Goodness of fit test is conducted to assess if the research model is acceptable or rejected. Using some conformity index and cut off the 15 criteria of goodness of fit there are three criteria that are less good, namely chisquare, probability and Hoelter. The rest, such as CM2 of 2,213, GFI 0.941, NFI 0.951, IFI 0.972 and CFI 0.972 are included in good fit category. So this research is said to be good fit. According Ghozali (2009) if two or more of all criteria of goodness of fit used has shown a good model (good fit) then the model can be said to be good or fit. From the above data, it can be seen that this research model is in good fit because 12 of 15 criteria included in the category of good fit or marginal fit that is still acceptable. 
Sylvia Diana Purba et al./ Psychological Meaningfulness and Work Engagement Effect on Doctor's Job....

Table 4. Hypothesis Result

\begin{tabular}{|c|c|c|c|c|c|c|}
\hline & & Estimate & S.E. & C.R. & $\mathbf{P}$ & Conclusions \\
\hline WE & $\leftarrow \mathrm{PM}$ & .794 & .082 & 9.649 & *** & Hypothesis accepted \\
\hline JS & $\leftarrow \mathrm{WE}$ & .635 & .137 & 4.546 & *** & Hypothesis accepted \\
\hline JS & $\leftarrow \mathrm{PM}$ & .089 & .124 & .692 & .489 & Hypothesis rejected \\
\hline
\end{tabular}

From the primary data that have been obtained by giving questionnaires to 150 doctors spread in Java Island, then performed some tests, such as validity test, reliability test, normality test, goodness of fit test, and structural model test. Validity test result was valid. For reliability test, all indicators such as psychological meaningfulness, work engagement and job satisfaction are reliable. Normality test results there is one abnormal construct, that is where two or dedication. This is still acceptable, because this research is the primary data obtained directly from the various respondents, making it difficult to obtain data that follows the normal distribution perfectly. For goodness of fit test this research model can be said good fit, because 12 of 15 criteria model obtained the following results: psychological meaningfulness has a significant effect on work engagement enter in good fit category or marginal fit. Ttest of the structural, as well as work engagement that affect the job satisfaction.

To test the hypothesis (Table 4), two hypotheses accepted namely the influence of psychological meaningfulness to work engagement as well as work engagement on job satisfaction. However, psychological meaningfulness has no effect on work engagement.

In addition, this study examined the effect of mediating work engagement on psychological meaningfulness with job satisfaction. The analysis results determine the effect of mediation is as follows.

Table 5. Test of Mediation

\begin{tabular}{llll}
\hline & $\begin{array}{l}\text { Direct } \\
\text { Effect }\end{array}$ & $\begin{array}{l}\text { Indirect } \\
\text { Effect }\end{array}$ & $\begin{array}{l}\text { Total } \\
\text { Effect }\end{array}$ \\
\hline $\mathrm{PM} \rightarrow \mathrm{WE}$ & .806 & .000 & .806 \\
$\mathrm{WE} \rightarrow \mathrm{JS}$ & .675 & .000 & .675 \\
$\mathrm{PM} \rightarrow \mathrm{JS}$ & .092 & .544 & .636 \\
\hline
\end{tabular}

Result of mediating variable (Table 5), it can be seen that psychological meaningfulness (PM) has a direct influence on work engagement (WE) of $80.6 \%$ (0.806) and work engagement (WE) to job satisfaction (JS) of $67.5 \%$ (0.675). While the influence of psychological meaningfulness (PM) on job satisfaction (JS) has no effect, it shows that the influence of psychological meaningfulness to job satisfaction is more perfect if mediated by work engagement.

It can be seen from the indirect effect column that the influence of PM to JS is $54.4 \%$ (0.544) which interprets that the influence of PM to JS is greater if not directly or need an intermediary to be able to influence JS variable.

\section{RESULT AND DISCUSSION}

\section{The Influence of Psychological Meaningful- ness on Work Engagement}

Based on the results of testing the value of Critical Ratio (C.R) of 9.649 with probability $^{* * *}$ or close to 0.000 it can be concluded that psychological meaningfulness has significant effect on work engagement or hypothesis accepted. This means that the higher the psychological significance of a person's work the higher the sense of being bound to the person's work. When a doctor feels his work is meaningful and has a positive impact on the environment, then a doctor will spend more time and strive to achieve maximum results. It can be said that he is already engaged or attached to his work. This result supported by previous research that psychological meaningfulness contributes to work engagement (Peral \& Geldenhuys, 2016). 


\section{The Influence of Work Engagement on Job Satisfaction}

In testing the second hypothesis, the influence of work engagement on job satisfaction shows the value of C.R. 4.546 with probability ${ }^{* * *}$ or close to 0.000 value can be concluded work engagement have significant effect to job satisfaction. This shows the more a person feels tied to his job, the more satisfied also with his work. When a physician feels tied to his work, such as being passionate about his work and despite much time to work, the doctor remains satisfied with his work, with one of the statements approved by the physician respondents in the study as the statement "I like things at this work".

It is necessary to provide a lot of time because it is related to the health of human life, a doctor still has this problem. The results of this study in accordance with research that has been done previously by Sartono and Ardhani (2015) that work engagement can improve one's job satisfaction.

\section{The Influence of Psychological Meaningful- ness on Job Satisfaction}

In the third hypothesis, the influence of psychological meaningfulness to job satisfaction yields the value of C.R 0.692 with probability 0.475. Value of C.R $<\mathrm{t}$-table (1.96) and probability $>0,05$ hence can be concluded psychological meaningfulness do not have significant influence to job satisfaction or hypothesis rejected. When a doctor realizes that his work is meaningful and meaningless, it does not mean that a doctor can immediately feel satisfaction with his work.

This result does not supported by Tanujaya (2014), that job satisfaction can affect psychological well-being, although the effect is small. By looking at the result of this research, there is influence between work engagements with job satisfaction, it can be assumed that psychological meaningfulness influence to job satisfaction by mediated by work engagement.

\section{The Influence of Psychological Meaningful- ness on Job Satisfaction with Work Engage- ment as a Mediating Variable}

In this study, test whether there is a significant influence between psychological mea- ningfulness to job satisfaction with work engagement as a mediation variable in the medical profession. Based on the test results, it is found that psychological meaningfulness does not have a significant effect on job satisfaction. However, psychological meaningfulness has a significant influence on job satisfaction mediated by work engagement of $9.6 \%$ obtained from the value of direct effect of PM (Psychological Meaningfulness) on JS (Job Satisfaction). In this study, work engagement as a mediating variable increases the influence between psychological meaningfulness and job satisfaction of $54.4 \%$ obtained from the value of PM (Psychological Meaningfulness) indirect effect on JS (Job Satisfaction). This shows the influence of psychological meaningfulness to job satisfaction will increase when mediated by work variables engagement so that the total effect of $63.6 \%$ and the rest of $36.4 \%$ explained by other variables.

A doctor who realizes that his or her work is meaningful and that it does mean and impacts on the surroundings will be more passionate and dedicated to his work as a doctor so they will tend to feel more satisfied or appear positive feelings in his work. Doctors' in Indonesia, especially for the ones who contributed on this study,will likely enhance their job satisfaction if they can engage with their works. This study showed that the doctors already have a high feeling to psychological meaningfulness and work engagement, as a result, in their current works' situations, they will still feel the satisfaction.

From the results of this study it is known that doctors will feel job satisfaction, if they feel enthusiasm, dedication and absorption in their work. That passion and dedication can be driven by a sense of meaning, positive and strong motivation. The doctors in this study were mostly young doctors, of which $65 \%$ were under 35 years old. They have high work engagement and consider their work to be very meaningful. Although the meaning of the work does not directly provide job satisfaction, the sense of meaning can increase 
Sylvia Diana Purba et al./ Psychological Meaningfulness and Work Engagement Effect on Doctor’s Job....

the perceived work engagement. With high absorption of work, doctors work outside of work hours and remain enthusiastic. This happened to doctors in this study. The number of doctors and the number of Indonesian population that is not comparable makes the doctors have to work beyond normal working hours. This situation can be resolved because doctors have psychological meaningfulness to their work. A high sense of meaning increases the spirit of dedication that makes them want to work with high workload demands even though the pay is not high. Such conditions occur in developing countries as well as in $\mathrm{Ni}$ geria (Martins et al., 2016), but not so in China where they are satisfied with the payment received (Yu et al., 2018). Therefore in Indonesia doctors often work in several hospitals and clinics (Setyowati et al., 2017). This is certainly not recommended even though there are quite a lot of patients. This can cause fatigue and will have an impact on service quality. In addition, it can also affect the health of the doctors in question.

\section{CONCLUSION AND RECOMMENDATION}

The results showed that psychological meaningfulness of work does not directly affect job satisfaction, but can increase work engagement and become a mediator in increasing job satisfaction. These results support the work situation of doctors in Indonesia who have high workloads but can still feel job satisfaction. With high work engagement, doctors feel enthusiasm and dedication even though the workload is high with working hours exceeding normal work hours.

Although the doctors in this study can feel job satisfaction because they have a psychological meaningfulness of work and high work engagement, but the government has time to think about how the problem of lack of doctors can be overcome. The government must also increase the income of doctors through government regulations so that doctors can focus on working in just one organization.
The are two limitations of this study, first, the samples are not random and second, the population is not counted, so these results cannot be generalized.

\section{REFERENCES}

Abbas, R. Z., Murad, H. S., Yazdani, N., \& Asghar, A. (2014). Extending "Kahn's Model of Personal Engagement and Disengagement at Work" with Reference to Existential Attributes. International Journal of Social Economics, 41(1), 2-31.

Adio, G., \& Popoola, S. O. (2010). Job Satisfaction and Career Commitment of Librarians in Federal University Libraries in Nigeria. Library Review, 59(3), 175-184.

Albrecht, S., Bakker, A., Gruman, J., Macey, W., \& Saks, A. (2015). Employee Engagement, Human Resource Management Practices and Competitive Advantage: an Integrated Approach. Journal of Organizational Effectiveness: People and Performance, 2(1), 7-35.

Asiwe, D., Rothmann, S., Jorgensen, L., \& Hill, C. (2017). Engagement of Employees in a Research Organisation: a Relational Perspective. South African Journal of Economic and Management Sciences, 20(1), 1-9.

Baharuddin, M., Lefrandt, R., \& Santosa, F. (2017). Tinjauan Etik Regulasi Jam Kerja Dokter di Indonesia, Jurnal Etika Kedokteran Indonesia, 1(1), 25-29.

Banihani, M., Lewis, P., \& Syed, J. (2013). Is Work Engagement Gendered?. Gender in Management: an International Journal, 28(7), 400423.

Byrne, Z., Manning, S., Weston, J. \& Hochwarter, W. (2017). All Roads Lead to Well-Being: Unexpected Relationships between Organizational. In Christopher C. Rosen, Pamela L. Perrewé (Ed.), Power, Politics, and Political Skill in Job Stress, 15,1-32.

Cai, Z., Huang, Q. Liu, H., \& Wang, X. (2018). Improving the Agility of Employees through Enterprise Social Media: the Mediating Role of Psychological Conditions. International Journal of Information Management, 38(1), 52-63.

Daley, D. (2017). Job Satisfaction versus Job Engagement: a Comparative Analysis on Perceptions of Accountability and Turnover, 
International Journal of Organization Theory \& Behavior, 20(2), 161-192.

Deng, S., Yang, N., \& Li, S. (2018). Doctors 'Job Satisfaction and its Relationships with Doctor-Patient Relationship and Work-Family Conflict in China: a Structural Equation Modeling. Inquiry: The Journal of Health Care Organization, Provision, and Financing, 55.

De Witte, H., \& Buitendach, J. H. (2005). Job insecurity, extrinsic and intrinsic job satisfaction and affective organisational commitment of maintenance workers in a parastatal. South African Journal of Business Management, 36(2), 27-37.

Fadlallh, A. W. A. (2015). Impact of Job Satisfaction on Employees Performance an Application on Faculty of Science and Humanity Studies University of Salman Bin AbdulAziz-Al Aflaj. International Journal of Innovation and Research in Educational Sciences, 2(1), 26-32.

Geldenhuys, M., Łaba, K., \& Venter, C. . (2014). Meaningful Work, Work Engagement and Organisational Commitment. Sa Journal Of Industrial Psychology/Sa Tydskrif Vir Bedryfsielkunde, 40(1), 1-10.

Ghozali, I. (2009). Aplikasi Analisis Multivariate Dengan Program SPSS. Semarang: Universitas Diponogoro.

Greenberg, J., \& Baron, R. A. (2003). Behavior in Organizations (Understanding \& Managing $\mathrm{Hu}$ man Side of Work) (8Th Ed.). Upper Saddle River, NJ: Prentice Hall.

Imperatori, B. (2017). Engagement and Disengagement at Work: Drivers and Organizational Practices to Sustain Employee Passion and Performance (1st Ed.). Italy: Springer International Publishing.

Kahn, W. A. (1990). Psychological Conditions of Personal Engagement and Disengagement at Work. Academy of Management Journal, 33(4), 692-724.

Karatepe, O. M., \& Demir, E. (2013), Linking Core Self-Evaluations and Work Engagement to Work-Family Facilitation: a Study in the Hotel Industry, International Journal of Contemporary Hospitality Management, 26(2), 307-323.

Ko, M. S., Lee, H. Z., \& Koh, M. S. (2017). Effects of Nurses' Social Capital and Job Engagement on Nursing Performance: Focused on the Mediating Effects of Organizational Citizenship
Behavior. Journal of Korean Academy of Nursing Administration, 23(1), 42-51.

Lu, L., Lu, A., Gursoy, D. \& Neale, N. (2016). Work Engagement, Job Satisfaction, and Turnover Intentions: a Comparison between Supervisors and Line-Level Employees. International Journal of Contemporary Hospitality Management, 28(4), 737-761.

Lockwood, N. R. (2007). Leveraging Employee Engagements for Competitive Advantage: HRS Strategic Role. HR Magazine, 52(3), 1-11.

Martins, O. F., Tukur, D., Danburam, A., \& Salwau, F. K. (2016). Job Satisfaction among Doctors and Nurses: a Case Study of Federal Medical Centre Yola, Nigeria. International Journal of Community Medical Public Health, 3(6), 1640-1647.

May, D. R., Gilson, R. L., Harter, L. M. (2004). The Psychological Conditions of Meaningfulness, Safety and Availability and the Engagement of the Human Spirit at Work. Journal of Occupational and Organizational Psychology, 77(1), 11-37.

Noblet, A. J., Allisey, A. F., Nielsen, I. L., Cotton, S., LaMontagne, A. D., \& Page, K. M. (2017). The Work-Based Predictors of Job Engagement and Job Satisfaction Experienced by Community Health Professionals. Health Care Management Review, 42(3), 237-246.

Oliver, Al., \& Rothmann, S. (2007). Antecedents of Work Engagement in a Multinational Oil Company. SA Journal of Industrial Psychology 33(3), 49-56.

Peral, S., \& Geldenhuys, M. (2016). The Effects of Job Crafting on Subjective Well-Being amongst South African High School Teachers. Sa Journal of Industrial Psychology, 42(1), $1-13$.

Sartono, H., \& Ardhani, M. (2015). Work Engagement, Intrinsic Motivation and Job Satisfaction among Employees of a Coal Mining Company in South Borneo. International Research Journal of Business Studies, 8(2), 107-122.

Sawang, S. (2012), Is there an Inverted U-Shaped Relationship between Job Demands and Work Engagement: the Moderating Role of Social Support?. International Journal of Manpower, 33(2), 178-186.

Schaufeli, W. B., Salanova, M., Gonzalez-Roma, V., Bakker, A. B. (2002). The Measurement of Engagement and Burnout: a Two Sample 
Sylvia Diana Purba et al./ Psychological Meaningfulness and Work Engagement Effect on Doctor’s Job....

Confirmatory Factor. Journal of Happiness Studies, 3(1), 71-92.

Setyowati, R., Priyotomo., \& Suharnomo. (2017). Investigating Organizational Commitment among Medical Doctors, Hospital Nurses and Two Other Professional Jobs: a Systematic Review. Global Journal of Health Science, 9(12), 99-106.

Steger, M.F., \& Dik, B. J. (2009). If One is Looking for Meaning in Life, Does it Help to Find Meaning in Work?. Applied Psychology Health and Well-Being, 1(3), 303-320.

Steger, M. F., Dik, B. J., Duffy, R. D. (2012). Measuring Meaningful Work: the Work and Meaning Inventory (WAMI). Journal of Career Assessment, 20(3), 322-337.

Tanujaya, W. (2014). Hubungan Kepuasan Kerja Dengan Kesejahteraan Psikologis (Psychological Well Being) Pada Karyawan Cleaner (Studi Pada Karyawan Cleaner yang Menerima Gaji Tidak Sesuai Standar UMP Di PT. Sinergi Integra Services, Jakarta). Jurnal Psikologi, 12(2), 126-322.

Ugwu, F. O., \& Onyishi, I. E. (2018). Linking Perceived Organizational Frustration to Work Engagement: the Moderating Roles of Sense of Calling and Psychological Meaningfulness. Journal of Career Assessment, 26(2), 220-239.

Walden, J., Jung, E. H., \& Westerman, C. Y. (2017). Employee Communication, Job Engagement, and Organizational Commitment: a Study of Members of the Millennial Generation. Journal of Public Relations Research, 29(2-3), 73-89.

Yin, N. (2018). The Influencing Outcomes of Job Engagement: an Interpretation from the Social Exchange Theory. International Journal of Productivity and Performance Management, 67(5), 873-889.

Yu, X., Zheng, M., Cheng, X., Xu, B., Tao, Z., Ding, J., Zhang, K., Jin, H., \& Xie, B. (2018). Job Satisfaction among Doctors from Jiangsu Province in China. Medical Science Monitor: International Medical Journal of Experimental and Clinical Research, 24(2), 71-62.

Zhong, L., Wayne, S. J., \& Liden, R. C. (2016). Job Engagement, Perceived Organizational Support, High-Performance Human Resource Practices, and Cultural Value Orientations: a Cross-Level Investigation. Journal of Organizational Behavior, 37(6), 823-844. 